\title{
Quarterly Report on Program Cost and Schedule
}

Third Quarter FY 1992

U.S. Department of Energy

Office of Civilian Radioactive Waste Management

Washington, DC 20585

\section{MASTER}


PURPOSELY LEFT BLANK 


\section{DISCLAIMER}

This report was prepared as an account of work sponsored by an agency of the United States Government. Neither the United States Government nor any agency thereof, nor any of their employees, make any warranty, express or implied, or assumes any legal liability or responsibility for the accuracy, completeness, or usefulness of any information, apparatus, product, or process disclosed, or represents that its use would not infringe privately owned rights. Reference herein to any specific commercial product, process, or service by trade name, trademark, manufacturer, or otherwise does not necessarily constitute or imply its endorsement, recommendation, or favoring by the United States Government or any agency thereof. The views and opinions of authors expressed herein do not necessarily state or reflect those of the United States Government or any agency thereof. 


\title{
DISCLAIMER
}

\author{
Portions of this document may be illegible \\ in electronic image products. Images are \\ produced from the best available original \\ document.
}




\section{PREFACE}

This report is intended to provide a summary of the cost and schedule performance for the Civilian Radioactive Waste Management Program. Historical and current cost profiles (extracted from the DOE Financial Information System) are presented for each of the major program elements. Also included in this report are the program schedule baseline, the status of near-term program milestones and the status of the Nuclear Waste Fund revenues and disbursements. This report includes data through June 1992. 
PURPOSELY LEFT BLANK 


\section{TABLE OF CONTENTS}

\section{Page}

1. COST AND SCHEDULE HIGHLIGHTS 1

2. NUCLEAR WASTE FUND OVERVIEW

Receipts, Disbursements and Net Balance Projections

2

Cost Profile for Total Nuclear Waste Fund

4

3. PROGRAM SCHEDULE

Program Schedule Baseline

6

Near-Term Milestone Summary

7

9

4. FIRST REPOSITORY

Cost Profiles

5. TRANSPORTATION

Cost Profile

6. MONITORED RETRIEVABLE STORAGE

Cost Profile

7. SYSTEMS INTEGRATION

Cost Profile

8. ENGINEERING DEVELOPMENT

Cost Profile

9. PROGRAM MANAGEMENT/TECHNICAL SUPPORT

Cost Profile 
PURPOSELY LEFT BLANK 


\section{SECTION 1. COST AND SCHEDULE HIGHLIGHTS}

The following are selected major milestones from the Operations Management Tracking System that were reported as complete for the third quarter of FY92.

\section{Yucca Mountain Site Characterization Project}

- $\quad$ Started Drilling Operations with LM-300 Drill Rig (May 1992)

- $\quad$ Obtained Underground Injection Control (UIC) Permit Modification (May 1992)

- $\quad$ Started Drilling for Soil and Rock Properties Ramp Boreholes (June 1992)

- $\quad$ Completed North Access Shallow Borehole (NRG-1) (June 1992)

\section{Monitored Retrievable Storage}

- $\quad$ M\&O Issued MRS Conceptual Design Report to DOE for Review (May 1992)

\section{Transportation}

- $\quad$ Completed Public Comment on Section 180(c) Strategy (May 1992)

Actual FY92 costs for the total Nuclear Waste Fund through the third quarter were $\$ 234.8$ million. Breakdown of cost by program element is as follows:

- $\quad$ Total First Repository costs - \$147.4 million ( $\$ 138.3$ million for the Yucca Mountain Site Characterization Project and the remainder for basalt and salt closeout, technical support and repository technology program activities).

- $\quad$ Transportation - $\$ 12.9$ million

- $\quad$ MRS - \$14.6 million

- $\quad$ Systems Integration - $\$ 10.0$ million

- $\quad$ Engineering Development - $\$ 5.5$ million

- $\quad$ Program Management/Technical Support - \$44.4 million 


\section{SECTION 2. NUCLEAR WASTE FUND OVERVIEW}

\section{RECEIPTS, DISBURSEMENTS AND NET BALANCE PROJECTIONS}

\section{Projection of Receipts and Disbursements}

- $\quad$ For FY 1983 through FY 1990, receipts were actual amounts collected from utilities while disbursements included actual disbursements and interest paid on the appropriated debt. The appropriated debt was repaid in FY 1985. Receipt and disbursement projections for FY 1992 through FY 1994 are based on information contained in the FY 1993 Congressional budget submission.

\section{Projected Net Balance}

- The current net balance projection (June 1992) assumes the revenues from the 1 mill per $\mathrm{kWh}$ fee contained in the Energy Information Administration projection dated September 1991. Revenues from the one time fee and earned interest are extracted from the FY 1993 Congressional budget submission. Disbursements for FY 1992 through FY 1994 assume the budget outlay estimates contained in the FY 1993 budget submittal.

- The January 1985 and February 1986 projections are provided to show the effect of the one-time payment for fuel generated before 1983 . The January 1985 projection assumed that $\$ 770$ million would be received in June 1985 for the one-time payment while the February 1986 projection reflects the fact that $\$ 1.4$ billion was actually collected.

- $\quad$ The February 1986 net balance projection assumed the cost estimates, revenues (both from the 1 mill per kWh fee and the one-time fee), and earned interest contained in the FY 1987 budget submittal.

- The January 1985 net balance projection was based on revenue and cost projections (escalated to current dollars by an average annual growth rate of 5 percent per year) in the FY 1986 budget submitted to Congress. The projection of net balance assumed that a positive yearly balance earns interest at a rate of 7 percent per year. 
PROJECTED NUCLEAR WASTE FUND RECEIPTS \& DISBURSEMENTS (AS OF 6/92)

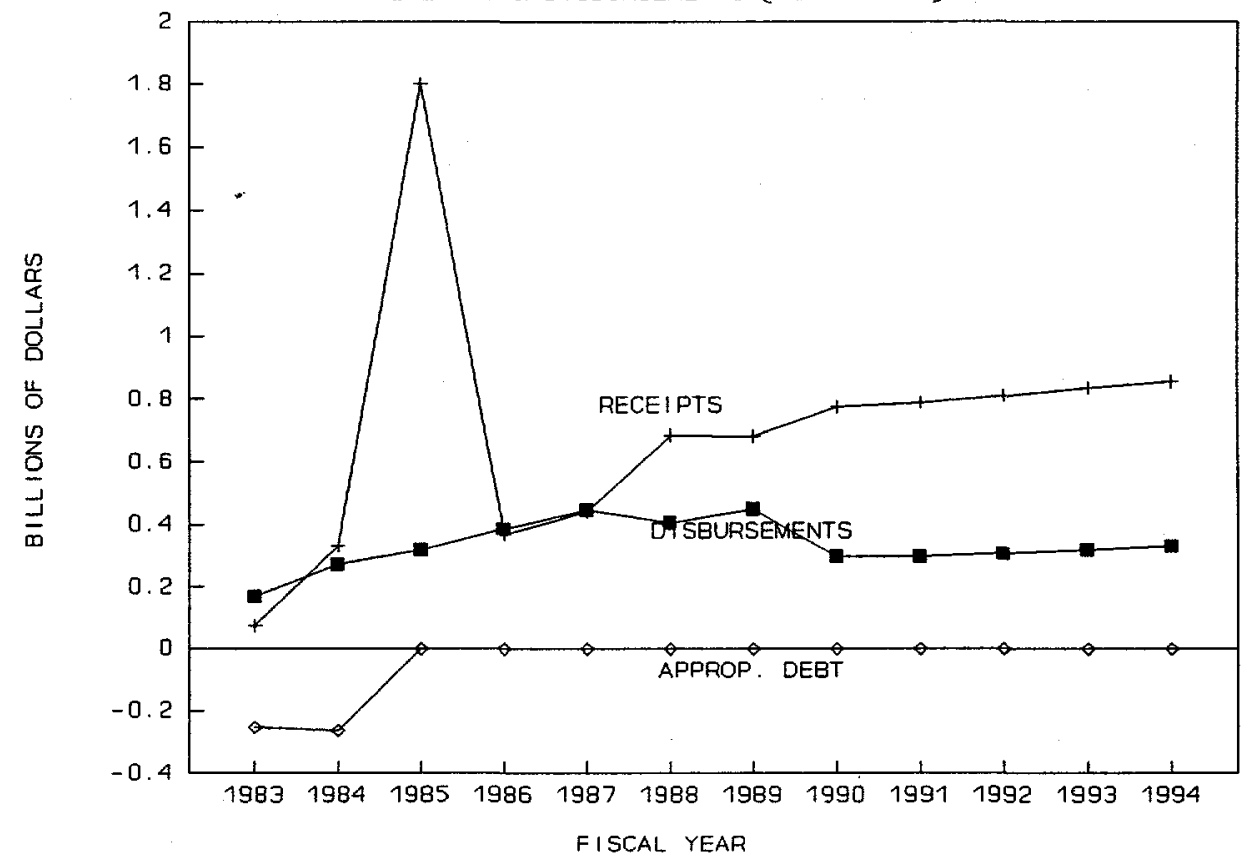

\section{PROJECTED NET BALANCE}

OF WASTE FUND

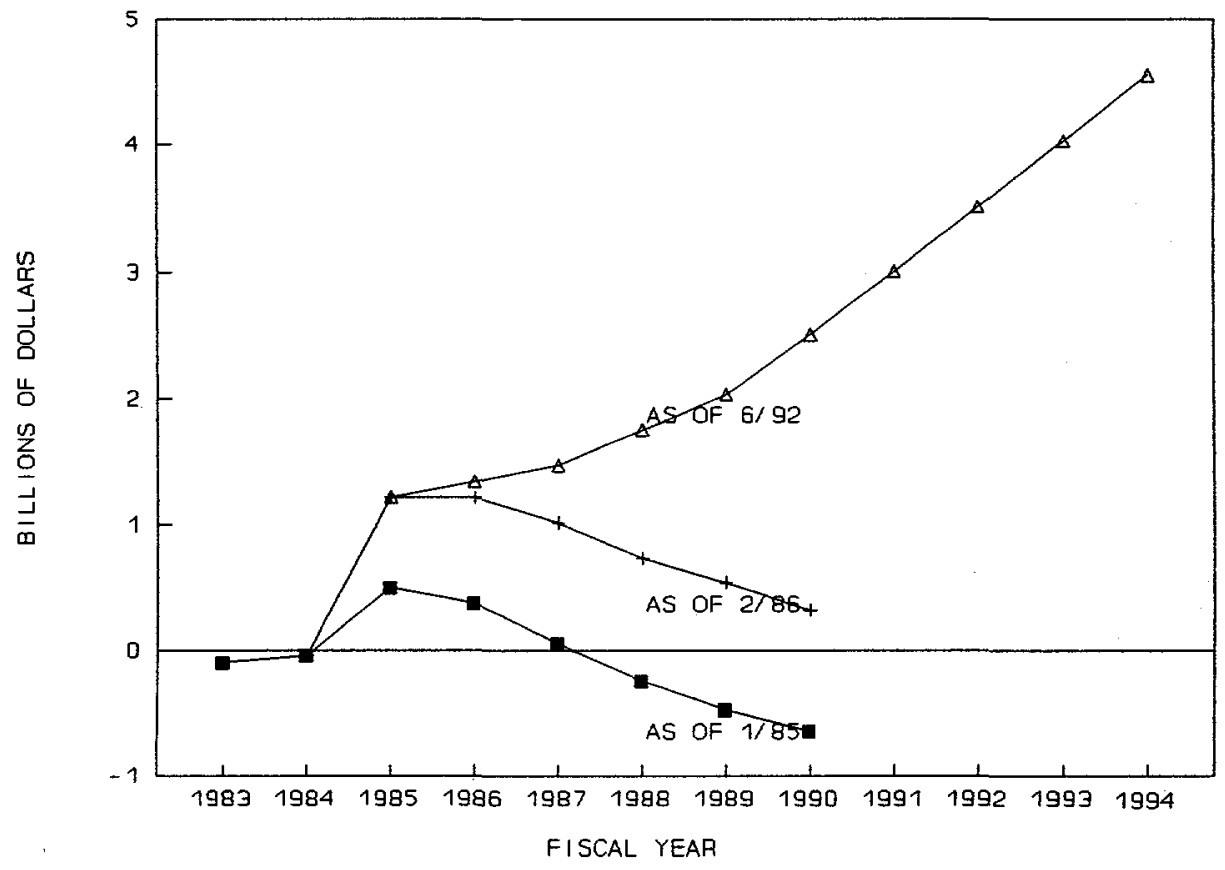




\section{COST PROFILE FOR TOTAL NUCLEAR WASTE FUND}

- FY92 actual costs through the third quarter for the Nuclear Waste Fund were \$234.8 million.

- Through the third quarter of FY92, cumulative actual costs (from FY83) for the entire program totaled $\$ 3,232.8$ million. 
COST PROFILE FOR TOTAL NUCLEAR WASTE FUND

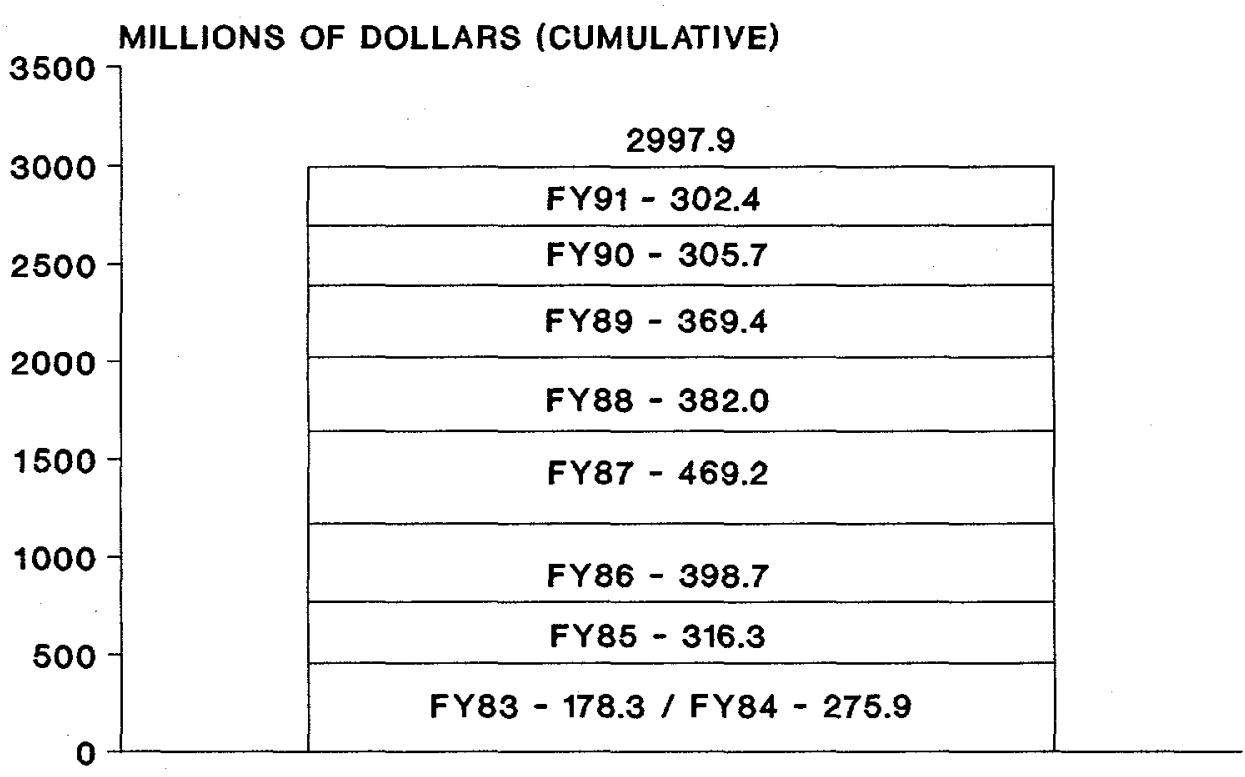

HISTORICAL

(ENTRIES MAY NOT ADD TO TOTAL DUE TO INDEPENDENT ROUNDING)

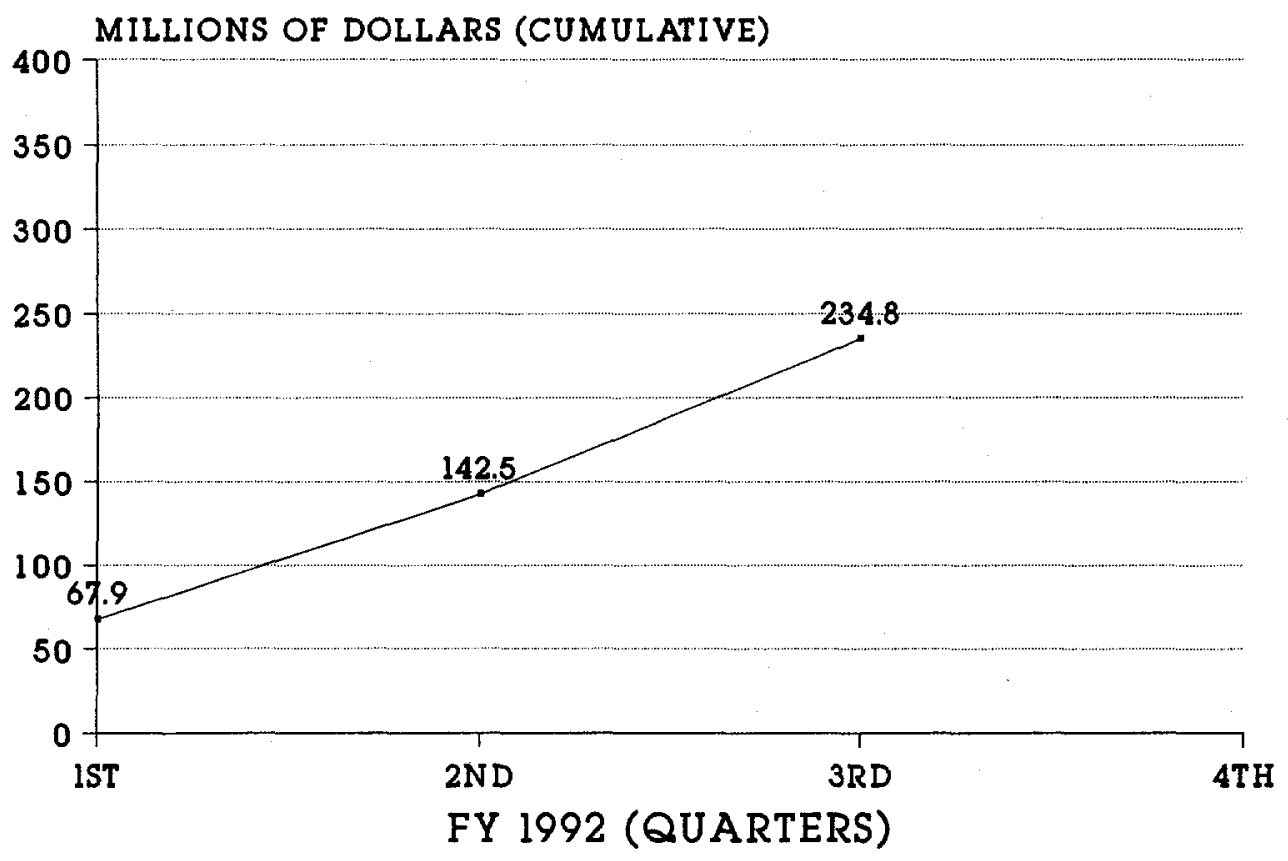




\section{SECTION 3. PROGRAM SCHEDULE BASELINE}

- $\quad$ Figure 1 represents the current program schedule as contained in the Program Cost and Schedule Baseline (PCSB), Revision 2. This schedule was approved by the OCRWM Program Change Control Board on November 1, 1991. 


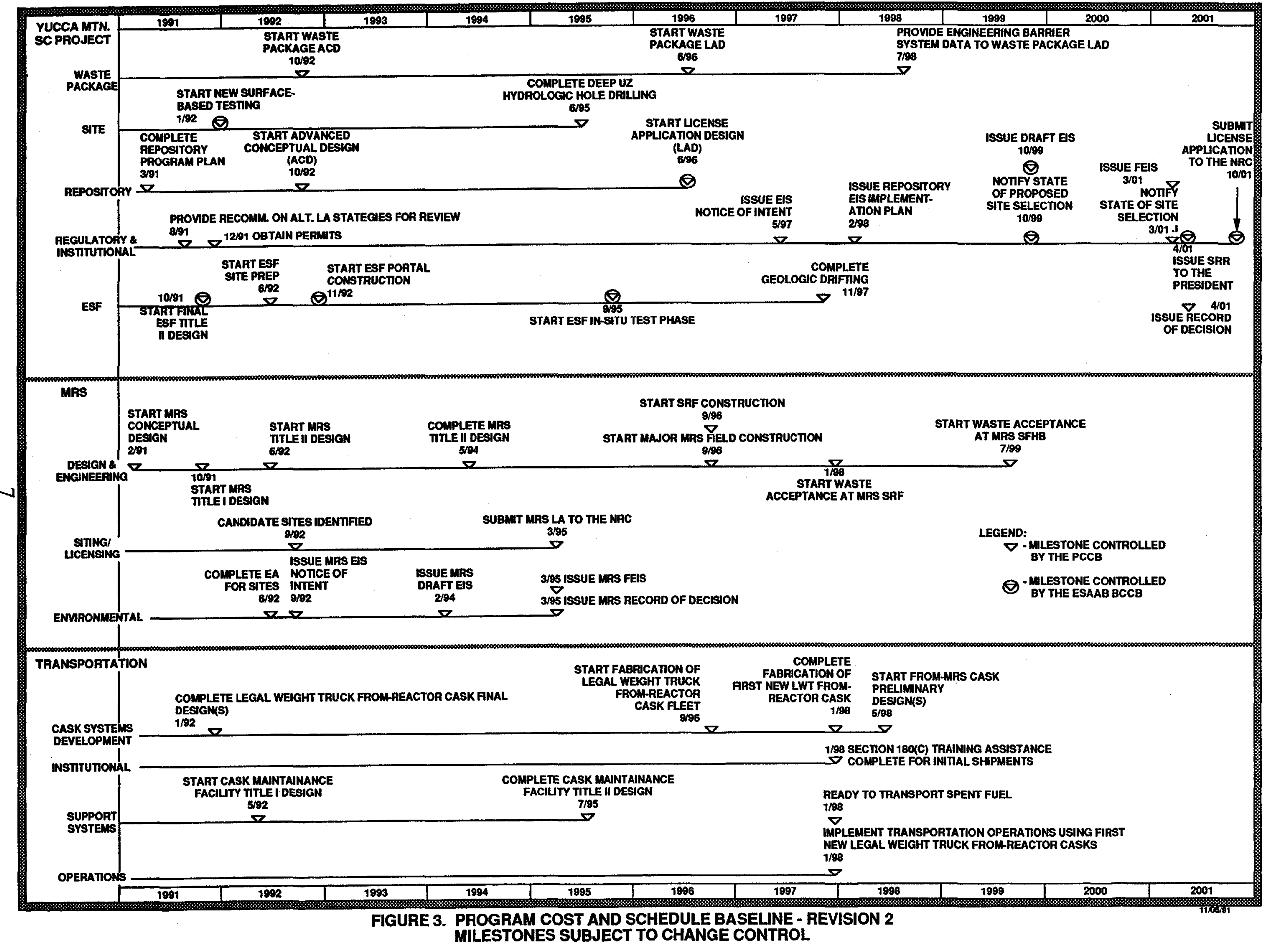


PURPOSELY LEFT BLANK 


\section{NEAR-TERM MILESTONE SUMMARY}

The following milestones were completed during the third quarter FY92 as reported in the Operations Management Tracking System.

\section{Program Management}

- $\quad$ Held First Directors Forum (May 1992)

- $\quad$ Conducted MRS ICE Kickoff Meeting (June 1992)

\section{Yucca Mountain Site Characterization Project}

- $\quad$ Started Drilling Operations with LM-300 Drill Rig (May 1992)

- $\quad$ Obtained Underground Injection Control (UIC) Permit Modification (May 1992)

- $\quad$ Started Drilling for Soil and Rock Properties Ramp Boreholes (June 1992)

- $\quad$ Completed North Access Shallow Borehole (NRG-1) (June 1992)

\section{Monitored Retrievable Storage Facility}

- $\quad$ M\&O Issued MRS Conceptual Design Report to DOE for Review (May 1992)

\section{Transportation}

- $\quad$ Conducted Transportation Coordination Group (TCG) Meeting (May 1992)

- $\quad$ Completed Public Comment on Section 180(c) Strategy (May 1992) 


\title{
SECTION 4. TOTAL FIRST REPOSITORY
}

\author{
COST PROFILE
}

- $\quad$ FY92 actual costs through the third quarter for the first repository were $\$ 147.4$ million. The distribution by project was $\$ 138.3$ million for the Yucca Mountain Site Characterization Project, $\$ 8.7$ million for technical support/repository technology program (RTP) activities, $\$ 0.6$ million for the basalt project (BWIP) closeout, and \$-.2 million for the salt project (SRP) closeout.

- $\quad$ Through the third quarter of FY92, cumulative actual cost (from FY83) for the first repository projects totaled $\$ 2,345.8$ million of which 51 percent (or $\$ 1,193.4$ million) was accounted for by YMP, 22 percent (or $\$ 514.2$ million) by SRP, 20.5 percent (or $\$ 482.7$ million) by BWIP, and 6.5 percent (or $\$ 155.5$ million) by technical support/RTP activities. 
COST PROFILE FOR TOTAL FIRST REPOSITORY

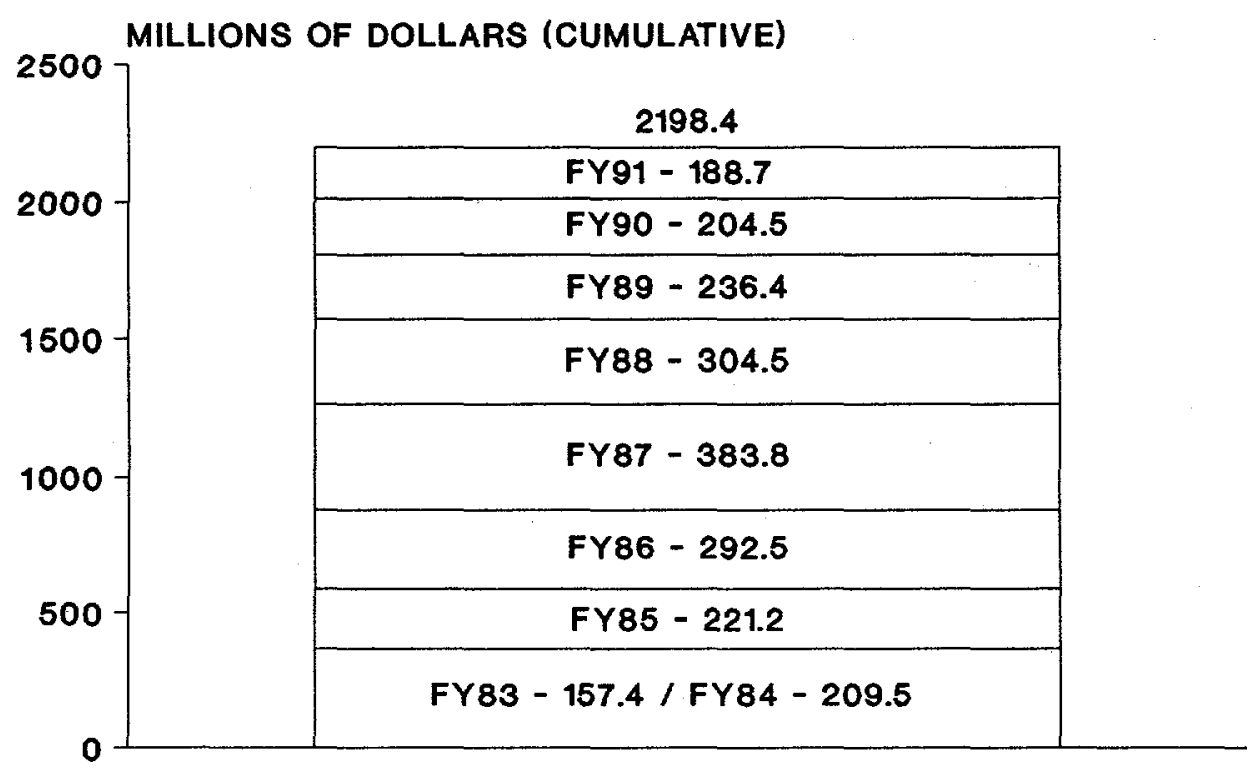

HISTORICAL

(ENTRIES MAY NOT ADD TO TOTAL DUE TO INDEPENDENT ROUNDING)

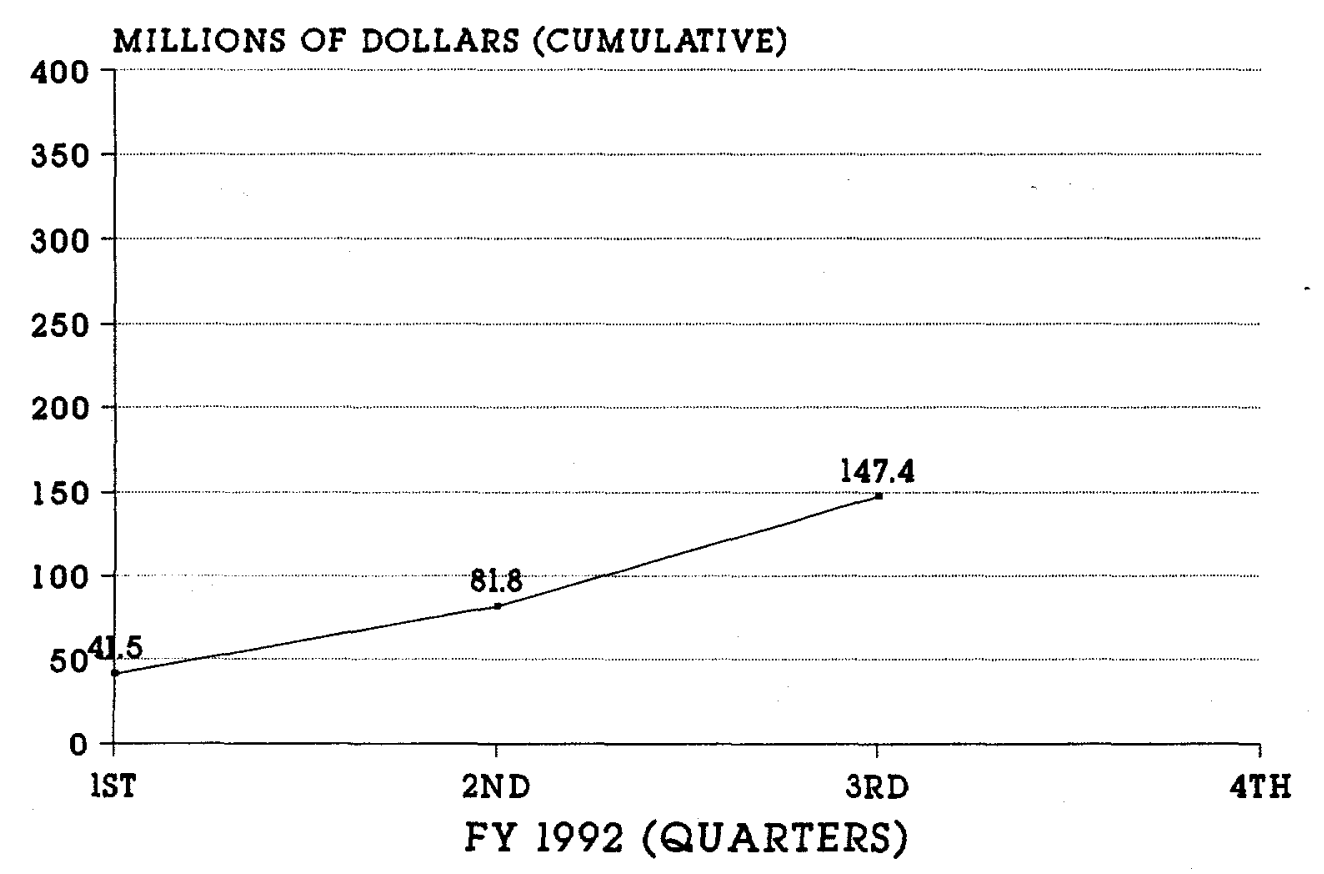




\section{COST PROFILES}

BWIP
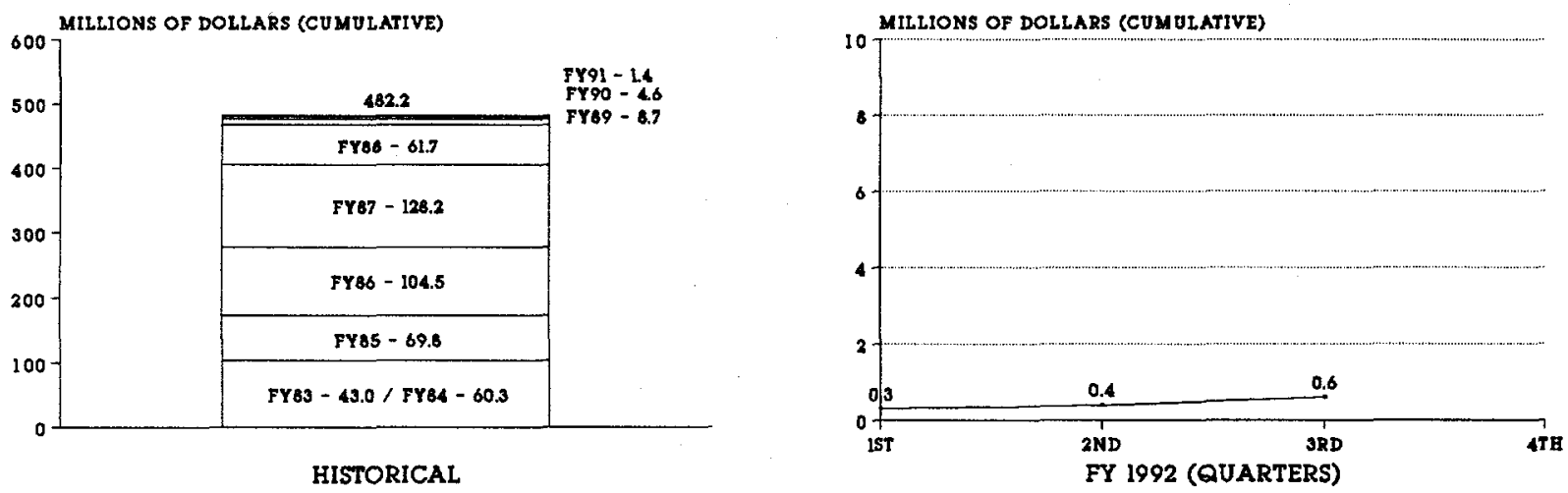

(ENTRIES MAY NOT ADD TO TOTAL DUE TO INDEPENDENT ROUNDING)

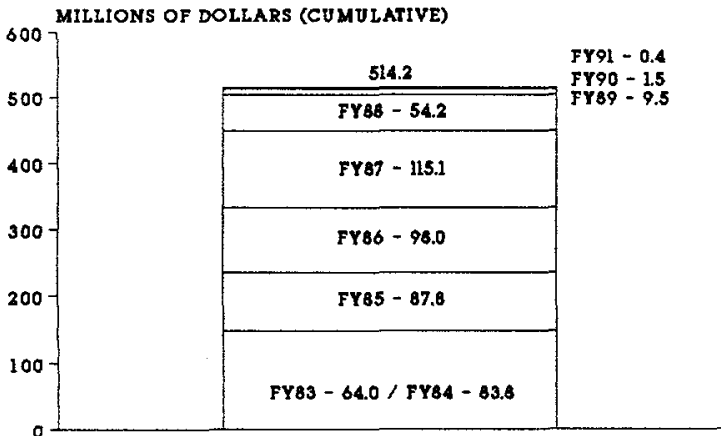

HISTORICAL

(ENTRIES MAY NOT ADD TO TOTAL DUE TO INDEPENDENT ROUNDING)

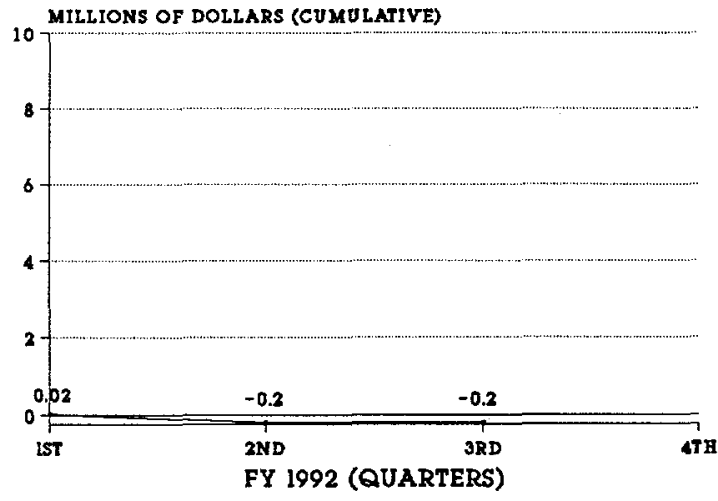




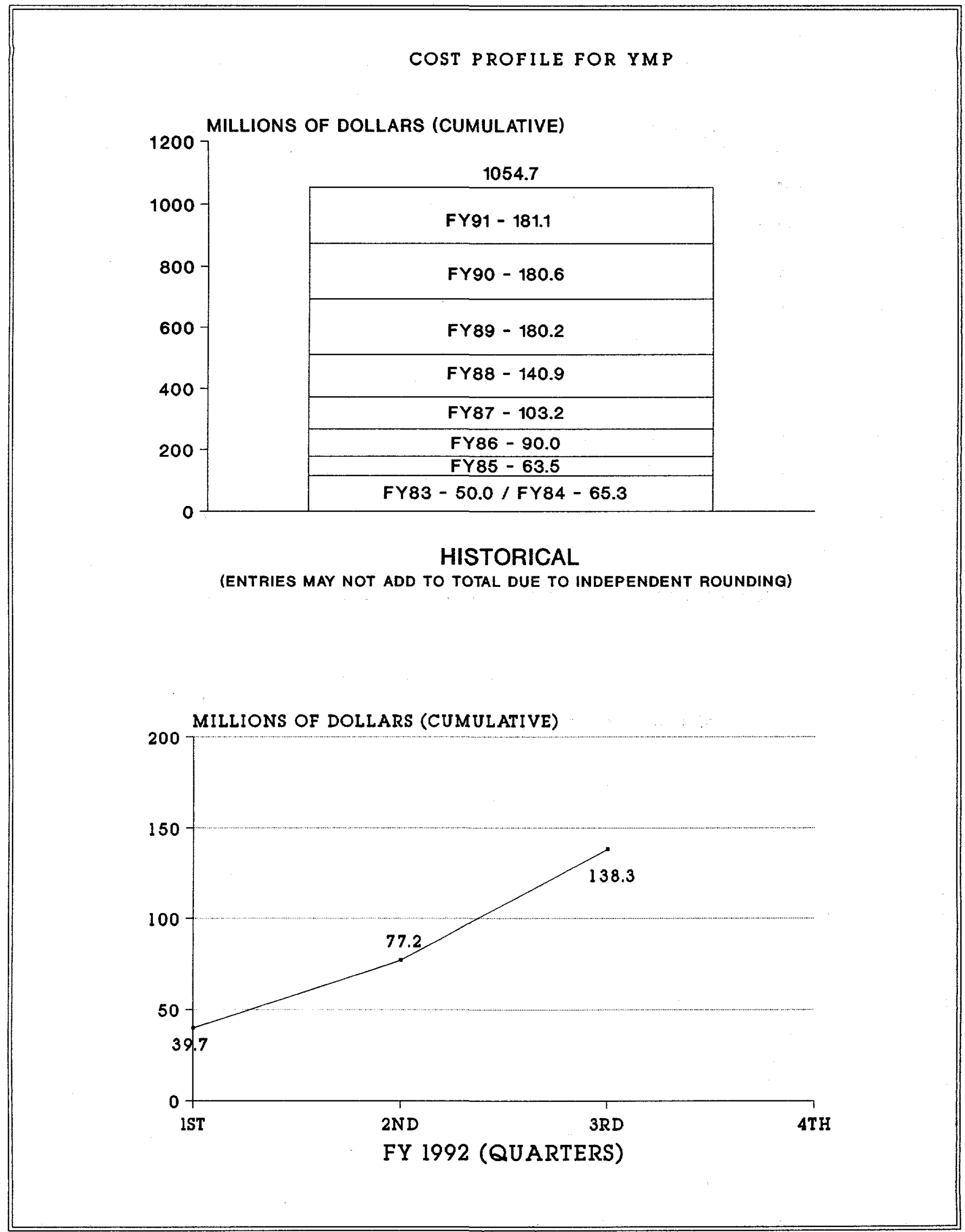


COST PROFILE FOR TECHNICAL SUPPORT/RTP

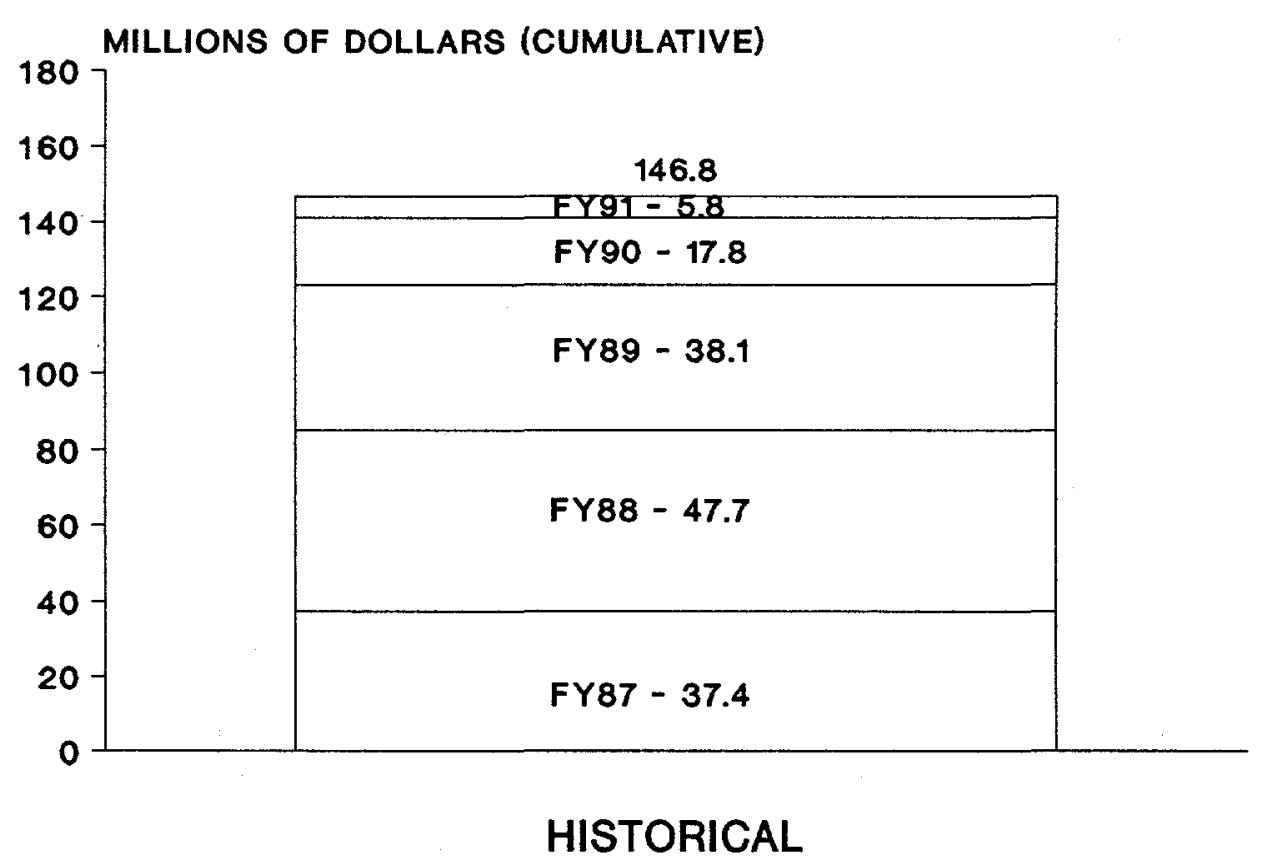

(ENTRIES MAY NOT ADD TO TOTAL DUE TO INDEPENDENT ROUNDING)

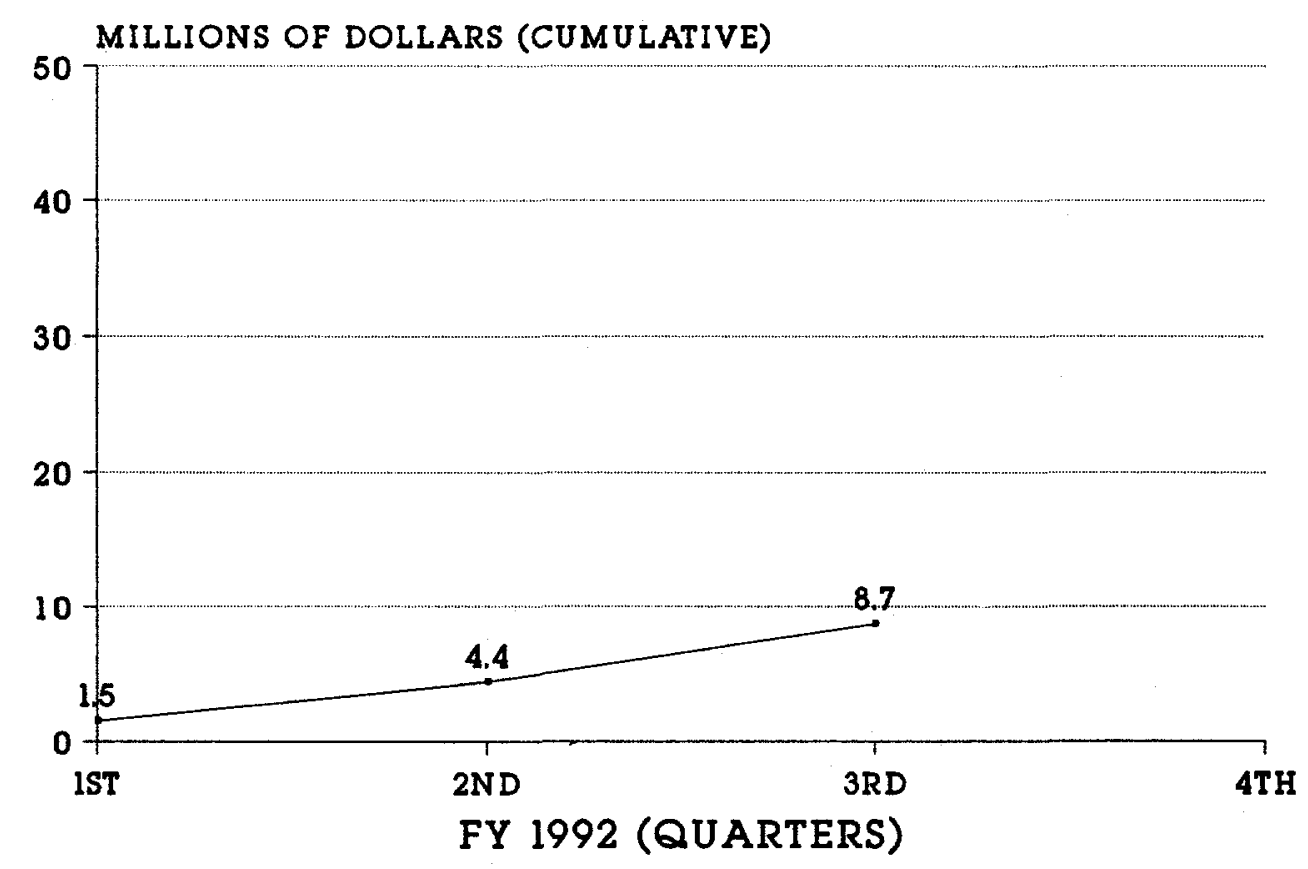




\section{PURPOSELY LEFT BLANK}




\section{SECTION 5. TRANSPORTATION COST PROFILE}

- FY92 actual costs through the third quarter were $\$ 12.9$ million.

- Through the third quarter of FY92 the cumulative costs since 1984 were $\$ 116.2$ million. 
COST PROFILE FOR TRANSPORTATION

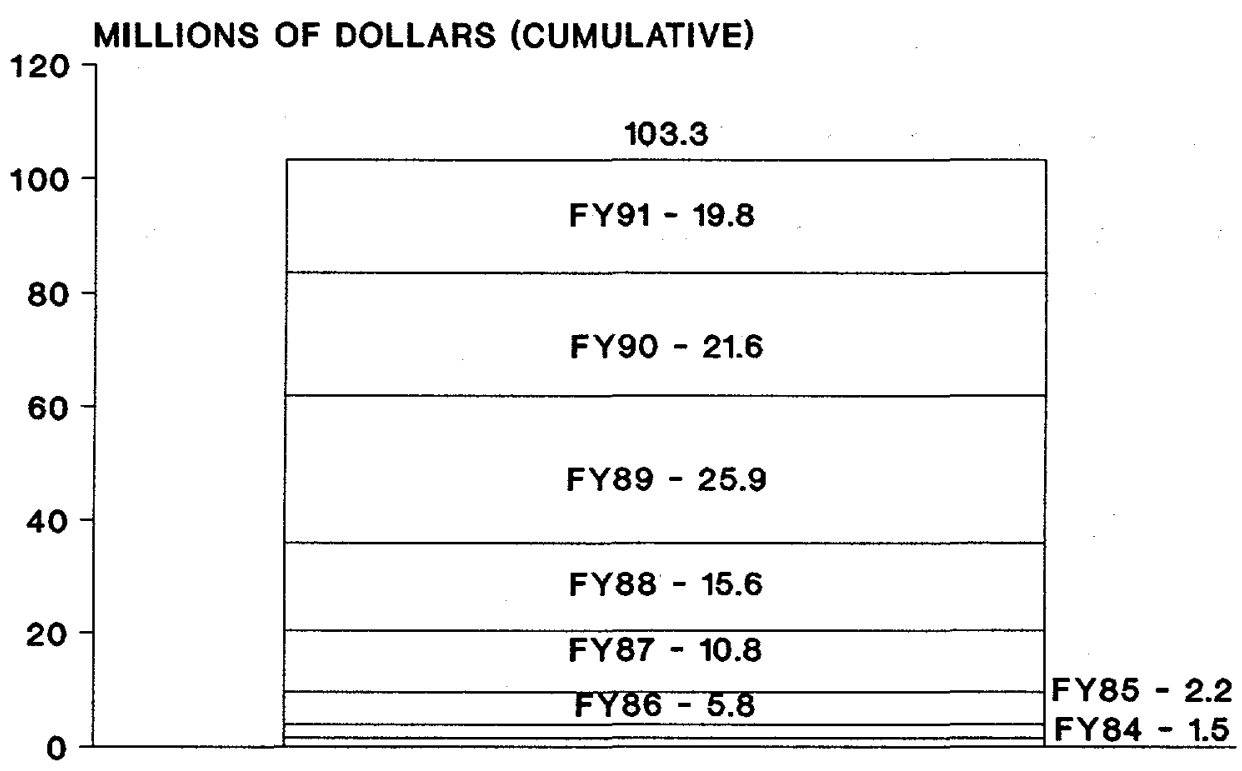

HISTORICAL

(ENTRIES MAY NOT ADD TO TOTAL DUE TO INDEPENDENT ROUNDING)

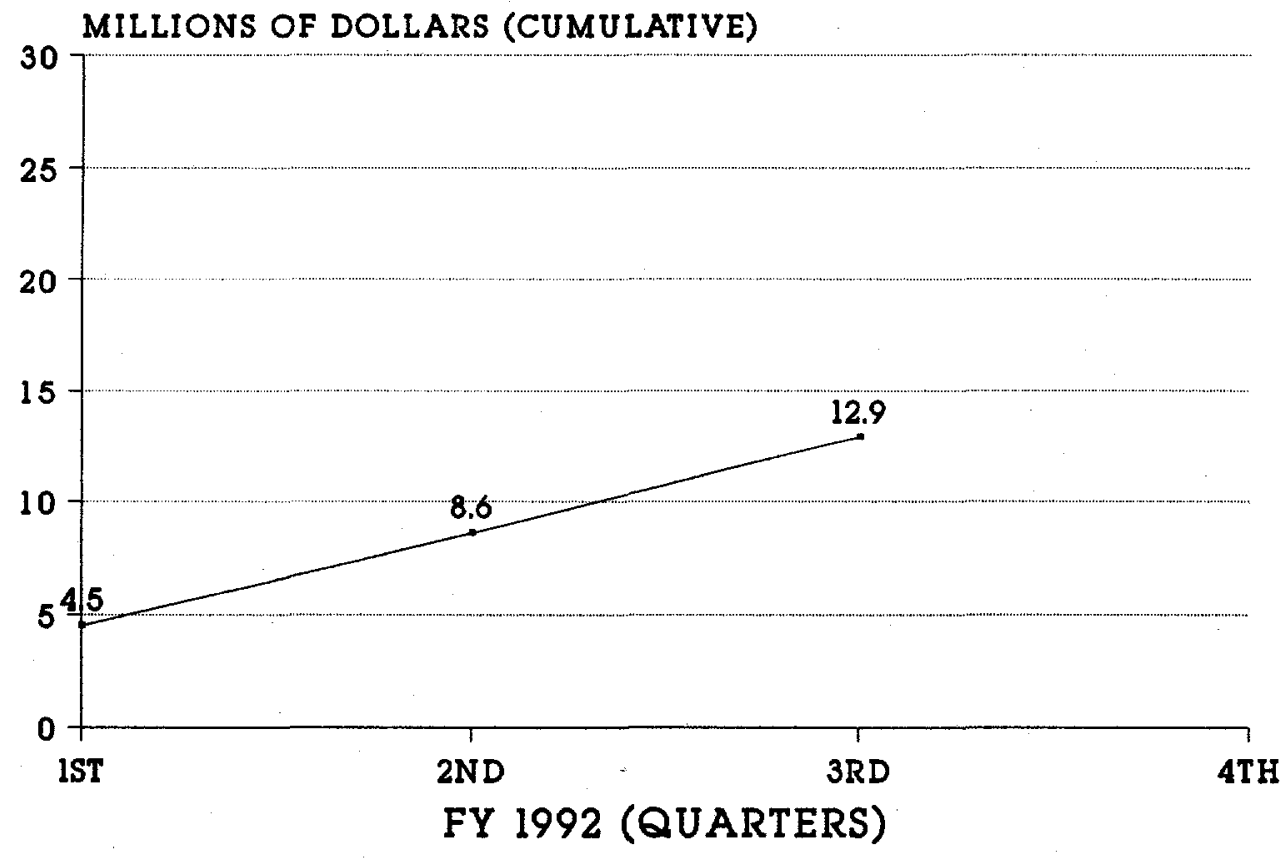




\section{SECTION 6. MONITORED RETRIEVABLE STORAGE COST PROFILE}

- FY92 actual costs for the MRS through third quarter were $\$ 14.6$ million.

- Through the third quarter of FY92, the cumulative costs since 1983 were $\$ 61.9$ million. 
COST PROFILE FOR MRS

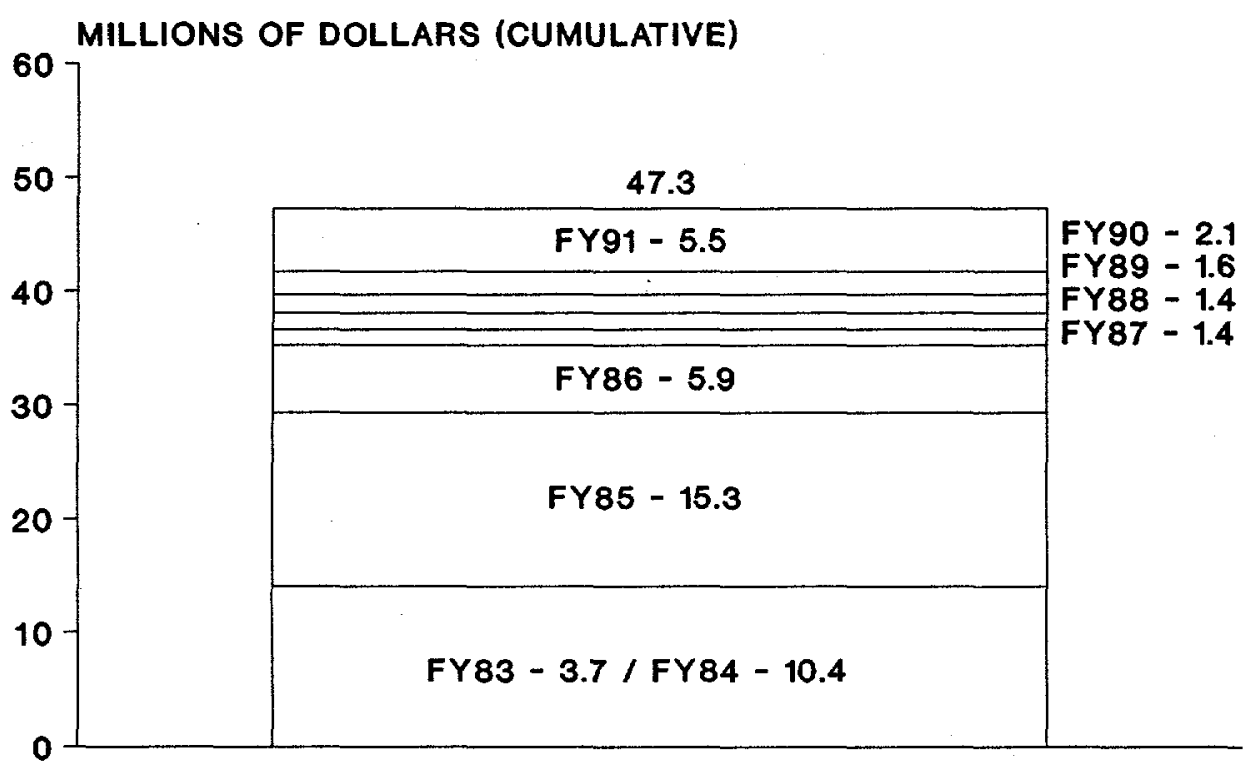

HISTORICAL

(ENTRIES MAY NOT ADD TO TOTAL DUE TO INDEPENDENT ROUNDING)

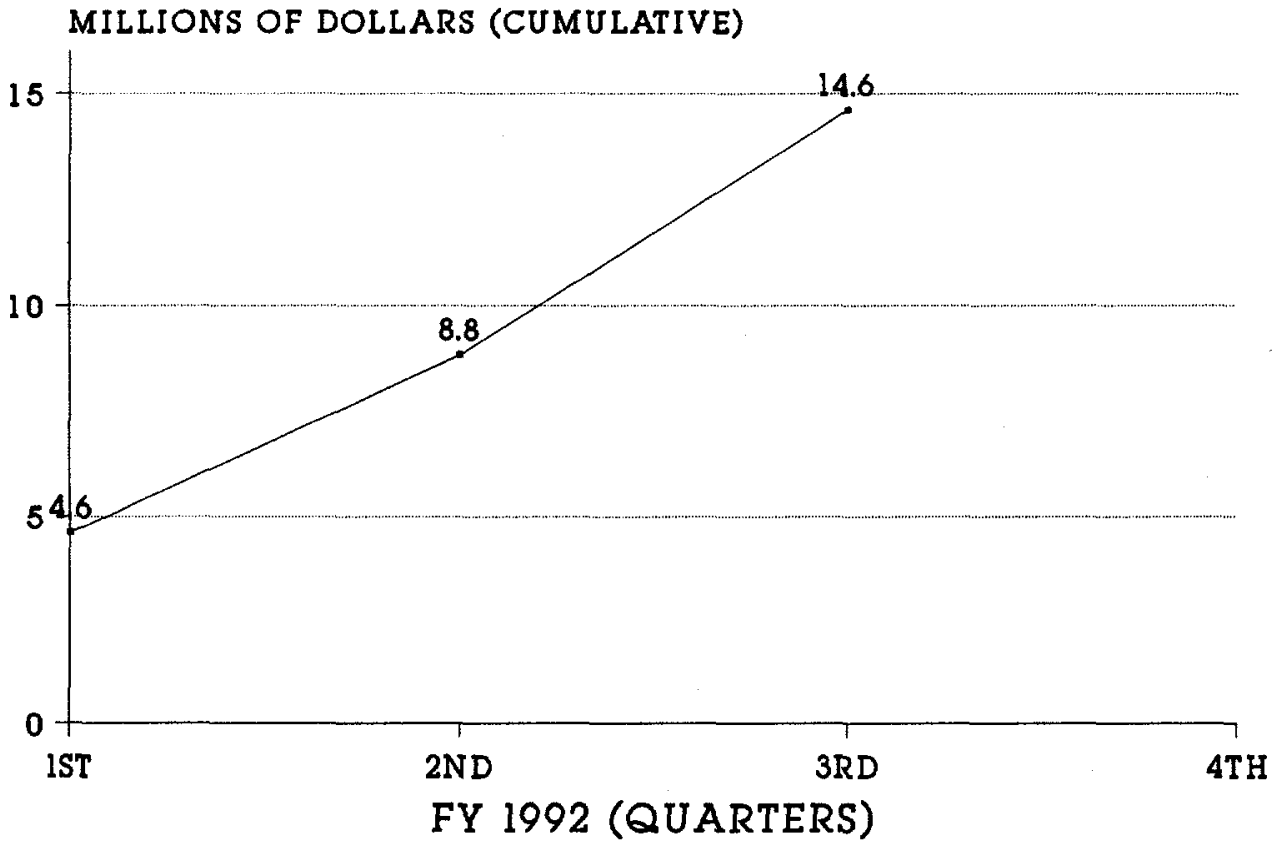




\section{SECTION 7. SYSTEMS INTEGRATION}

\section{COST PROFILE}

- FY92 actual costs for combined systems integration activities through the third quarter were $\$ 10.0$ million.

- Through the third quarter of FY92, the cumulative costs since 1985 were $\$ 61.8$ million. 


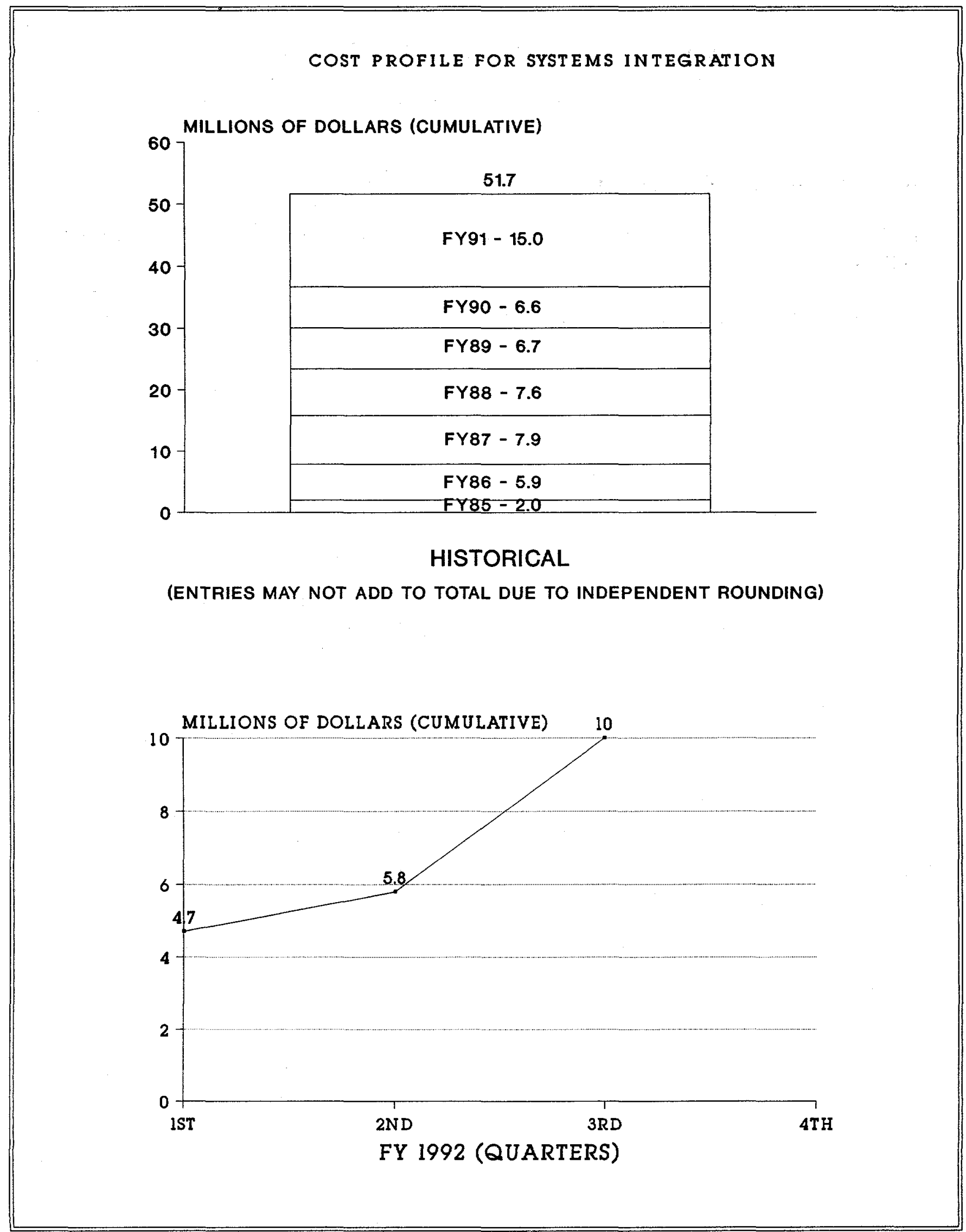




\section{SECTION 8. ENGINEERING DEVELOPMENT COST PROFILE}

- Work on engineering development is administered through the Idaho Operations Office.

- FY92 actual costs through the third quarter for the engineering development activities were $\$ 5.5$ million.

- Through the third quarter of FY92, the cumulative costs since 1985 were $\$ 51.9$ million. 


\section{COST PROFILE FOR ENGINEERING DEVELOPMENT}

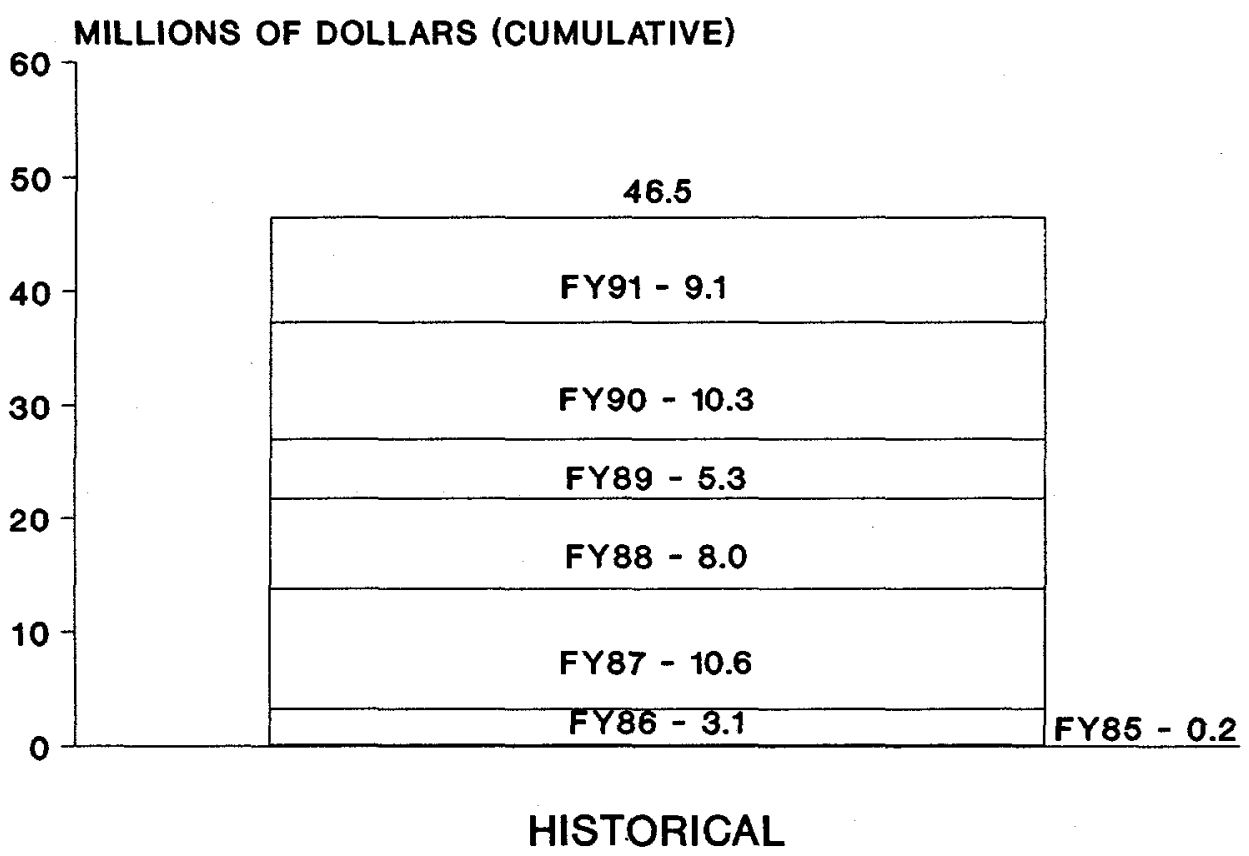

(ENTRIES MAY NOT ADD TO TOTAL DUE TO INDEPENDENT ROUNDING)

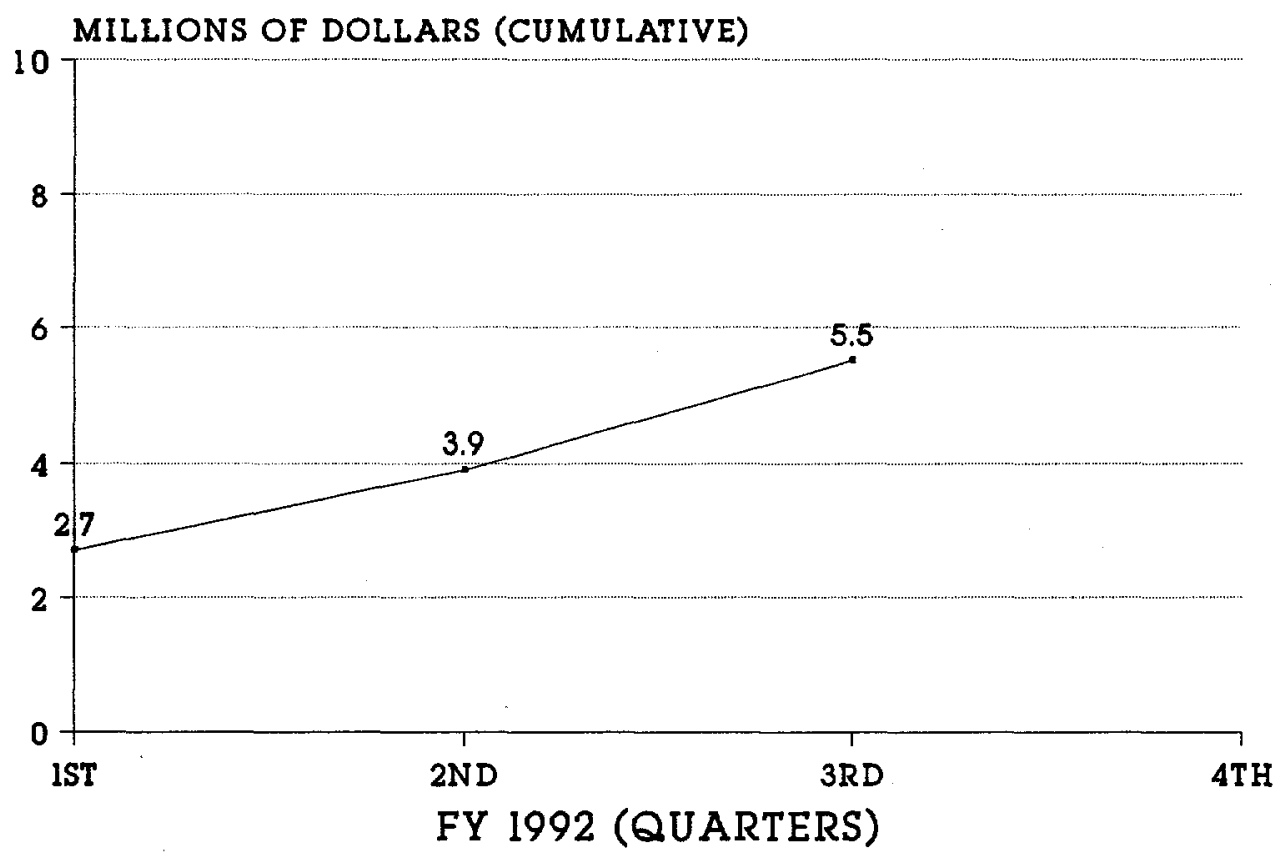




\section{SECTION 9. PROGRAM MANAGEMENT/TECHNICAL SUPPORT COST PROFILE}

- $\quad$ Activities include program management (federal salaries, benefits, and travel); contractual services (administrative support costs); and technical support (i.e., NWF audit services and fee verification, technical support activities, program integration, external relations and policy); and debt service.

- FY92 actual costs through the third quarter for the program management/technical support activities were $\$ 44.4$ million.

- Through the third quarter of FY92, the cumulative costs since 1983 were $\$ 513.9$ million (includes NRC fees). 
COST PROFILE FOR PROGRAM MANAGEMENT/TECHNICAL SUPPORT

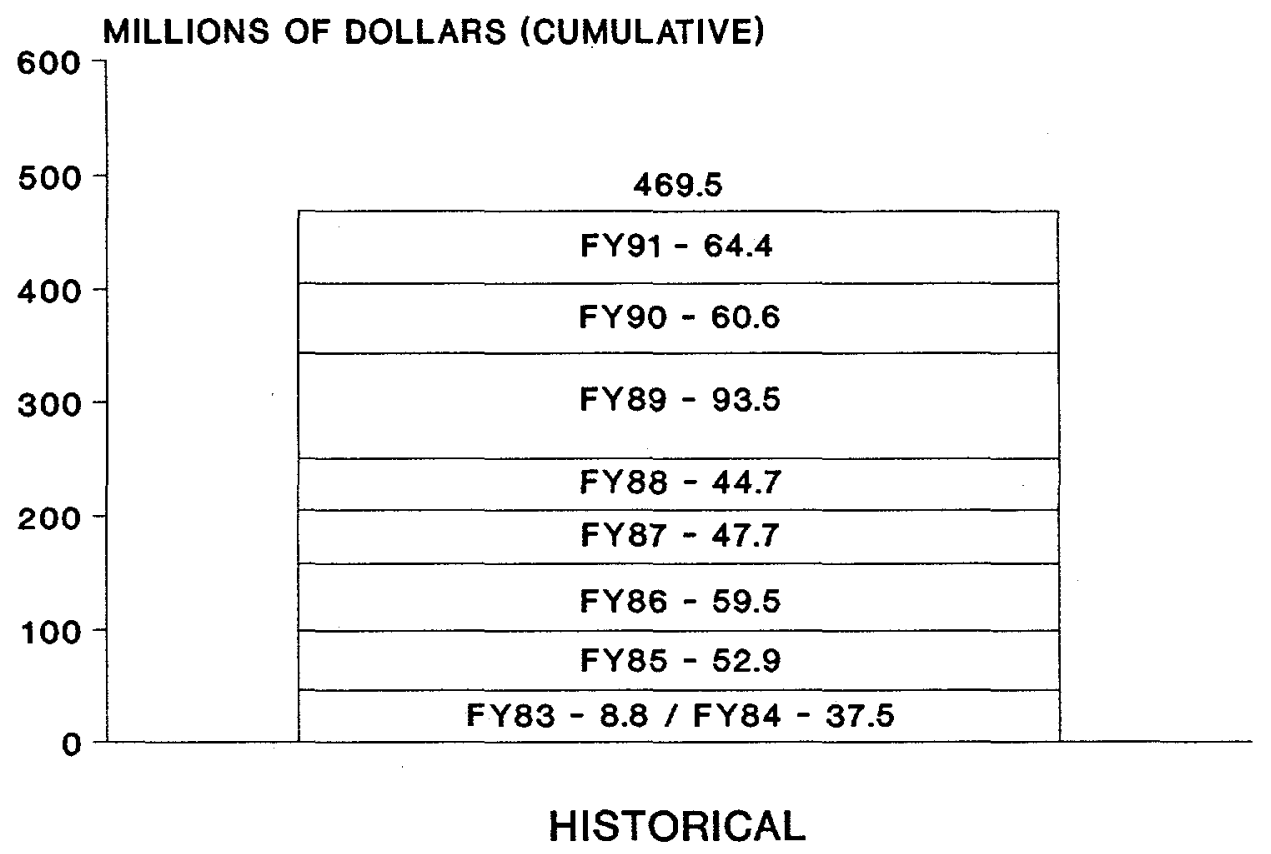

(ENTRIES MAY NOT ADD TO TOTAL DUE TO INDEPENDENT ROUNDING)

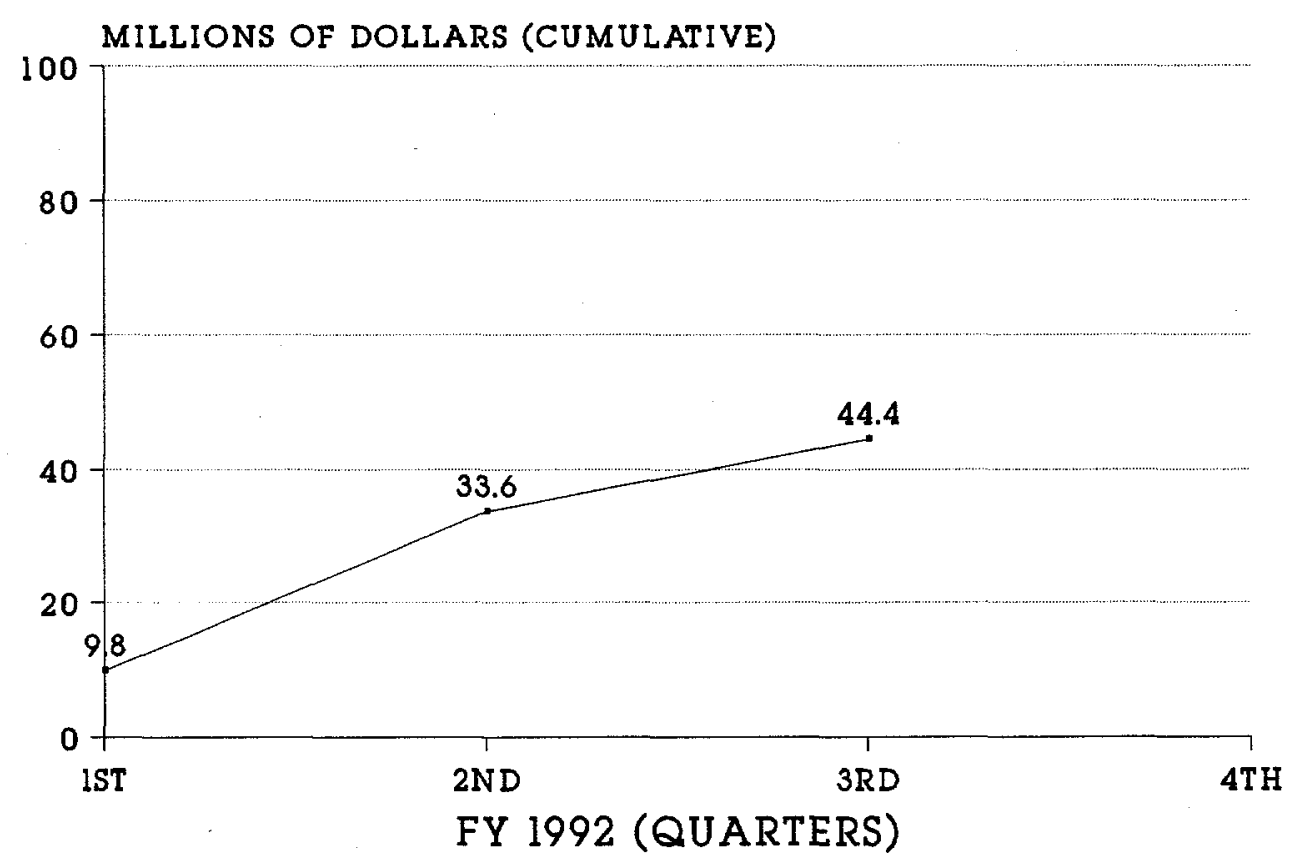

